\title{
From the Inquisition Pyre to Insertion into the Church: The Familial and Social Trajectory of Hernando Ortiz, a Jewish Convert in the Spanish Empire in the 16th Century
}

\author{
Clara Ramirez (iD
}

Citation: Ramirez, Clara. 2021. From the Inquisition Pyre to Insertion into the Church: The Familial and Social Trajectory of Hernando Ortiz, a Jewish Convert in the Spanish Empire in the 16th Century. Social Sciences 10: 264. https://doi.org/10.3390/ socsci10070264

Academic Editor: Nigel Parton

Received: 6 January 2021

Accepted: 30 April 2021

Published: 9 July 2021

Publisher's Note: MDPI stays neutra with regard to jurisdictional claims in published maps and institutional affiliations.

Copyright: (C) 2021 by the author. Licensee MDPI, Basel, Switzerland This article is an open access article distributed under the terms and conditions of the Creative Commons Attribution (CC BY) license (https:// creativecommons.org/licenses/by/ $4.0 /)$
Institute for Research on University and Education, National Autonomous University of Mexico, Mexico City 04510, Mexico; clarar@unam.mx

\begin{abstract}
This is a study of the trajectory of a Jewish converso who had a brilliant career at the University of Mexico in the 16th century: he received degrees from the faculties of arts, theology and law and was a professor for more than 28 years. He gained prestige and earned the respect of his fellow citizens, participated in monarchical politics and was an active member of his society, becoming the elected bishop of Guatemala. However, when he tried to become a judge of the Inquisition, a thorough investigation revealed his Jewish ancestry back in the Iberian Peninsula, causing his career to come to a halt. Further inquiry revealed that his grandmother had been burned by the Inquisition and accused of being a Judaizer around 1481; his nephews and nieces managed, in 1625 , to obtain a letter from the Inquisition vouching for the "cleanliness of blood" of the family. Furthermore, the nephews founded an entailed estate in Oaxaca and forbade the heir of the entail to marry into the Jewish community. The university was a factor that facilitated their integration, but the Inquisition reminded them of its limits. The nephews denied their ancestors and became part of the society of New Spain. We have here a well-documented case that represents the possible existence of many others.
\end{abstract}

Keywords: Jewish converts; university; New Spain; Inquisition; exclusion; bureaucracy

\section{Introduction}

Hernando Ortiz de Hinojosa constitutes a case, among many potential others, in which the colonial university contributed to conceding civil, political and social rights to a converso (a Jew who converted to Catholicism) born in Mexico City in 1544 (Ramírez González 2019). We know his story only because he wanted to be a judge of the Inquisition Tribunal. Otherwise, he would have remained unknown. Historical research has found much value in the individual experiences that come to light through exceptional circumstances because they raise questions about the achievements made possible by supposedly successful institutions or legal restrictions. The importance of this type of work was highlighted by Carlo Ginzburg, in 1976, with his work Il formaggio e i vermi. Il cosmo di un mugnaio del '500. He showed how a single case can dismantle generalizing stories and open windows to new possibilities, perhaps impossible to prove due to a lack of further historical documentation.

The purpose of this article is to show the role of the university in the process by which the society of New Spain integrated a Jewish family provided they denied their origins. As it is well known, those who persisted in their faith were prosecuted by the Inquisition Courts (Israel 2002; Ginzburg 1976; Gojman Goldberg 1984).

Conversely, Hernando de Ortiz was able to assimilate via the university system by denying his initial religion and adopting Christianity. Those steps would have been impossible if Ortiz's parents had not migrated from Andalucía to New Spain six years before he was born (Ramírez González 2013). In America, university degrees in the arts, theology and law allowed Ortiz to demonstrate his conformity with the policies of the colonial government established by the Spanish monarchy in what is now Mexico. 
This article is based on the careful analysis of three types of documentary files. First, I looked into the paperwork resulting from the investigation carried out by the Inquisition Court to ascertain Ortiz's "Limpieza de Sangre" (racial purity of cleanliness of blood), when he endeavored to become a judge of the aforementioned Tribunal. The testimonies of all the witnesses interrogated are preserved in the files, which may be found both in New Spain and in the Iberian Peninsula. There is a copy of the documents in the General Archives of the Nation, in Mexico, in the Inquisition Branch, as the original ones located in Spain disappeared. Second, I analyzed the files documenting the competition to achieve university professorship; those are in the same archives, in the University Branch. Finally, I resorted to various "Relaciones de Méritos" (records of services) that Ortiz used to prove his diligence to the king. Those are found in the General Archives of the Indies. It is a complex documentation, which may not be fully developed in this short article, but which I studied in depth in two books. I shall refer to them in this article (Ramírez González 2013, 2019).

The trajectory followed by Hernando Ortiz has laid out a template for the careers of other children of Spanish citizens born in America and has shown the potential and the limits of promotion by a university founded "in a land where greed reigns", according to the terminology used by one of his peers (de Salazar [1554] 2001). Ortiz studied at the University of Mexico between 1560 and 1580, obtaining all the degrees offered by universities at that time, except for a medical degree. He was a professor and a consultant for several novo-Hispanic institutions. Furthermore, he became a secular clerk, starting from the minor orders and making it to the top of the church hierarchy, and he then became the bishop of Guatemala. When he decided to try and reach the highest position in the Inquisition Court, that of qualifying judge, the high inquisitor demanded that a thorough investigation be conducted to prove that his ancestors had not been Jewish or converted Jews, in order to grant to him proof of what was then called "cleanliness of blood". In the Iberian Peninsula, such a certificate was required not only from those aiming for a high seat in the Inquisition Tribunal but also from the individuals wanting to join universities and hold functions linked to the monarchy (Caro Baroja 2000). In Mexico, all the witnesses who testified for him vouched for the fact that Ortiz was a descendant of "old Christians" and not of Jews. As a consequence, he was appointed Inquisition judge while the Supreme Inquisition validated the process. However, the Supreme Inquisition in Madrid sent the inquiry to the Inquisition of Seville so that the elderly people of Sanlúcar de Barrameda, the town where his parents had been born and where his grandparents lived, could be interrogated on Ortiz's ancestors. The elderly people of the town had not forgotten that Hernando de Sanlúcar, grandfather of the American doctor, used to be known as "king of the Jews", since he was their leader. Moreover, in the Inquisition of Seville, a 1534 declaration made not long before his departure to America by Diego Ortiz, Hernando's father, was found where he acknowledged that his grandmother had been sentenced and that his grandfather and mother were conversos.

The inquiry was sent back to Mexico City with an order from the Supreme Inquisition that Hernando Ortiz should be barred from all the public functions he occupied, including that of inquisitorial judge, since they were forbidden to people of Jewish descent. He was allowed to retain his ecclesiastical functions: as a canon of the Mexico cathedral and as bishop-elect of Guatemala. Ortiz died two years later, in 1598, at the age of 54, without recovering the bishopric to which he had been elected (Ramírez González 2019).

The case of Hernando Ortiz is not an isolated one, but when compared to others, it is particularly well documented. As a scholar and a clergyman, Ortiz was a man who trusted institutions; therefore, he wrote extensively and also requested that much about his life and career be written. We probably know more about him today than we do about any of his contemporaries (Ramírez González 2013, 2019). However, until recently, his life had not been reassessed. References to Hernando Ortiz de Hinojosa are dispersed in several works by (Schwaller 1987), (Poole 2011) and (Dussel 1970), and much of the information supplied remained imprecise or secondary. Recently, I and other authors have reexamined 
the importance of this figure (Pavón 2010; Nesvig 2009; Lundberg 2009; Carrillo Cázares 2006-2011; Ramírez González 2013, 2019).

Today, we know that the ancestry of this historical figure harks back to an even earlier time: his great-grandmother was burned by the Inquisition in Seville around 1481; his grandparents were protected by the Dukes of Medina Sidonia in Sanlúcar de Barrameda, from where Ortiz's parents left for Mexico City in 1538, despite the prohibitions placed upon emigration to America for Jews and their descendants (de Cadenas 1988). In the colonial city, members of Hernando Ortiz's family became "old colonizers" thanks to an uncle of the mother who was a Dominican friar. They changed their last names and forgot about their ancestors. Legitimized by Hernando Ortiz's university achievements, his nephews managed to found a Mayorgazo (entail) in Oaxaca. The entail was an institution that allowed for lands and privileges to be inherited by the eldest son of a family in order to promote the creation of a fortune precluding the division of the assets into individual, separate bequests (Taylor 1972). This institution ensured that the family name would prevail for Ortiz's nephews and secured the possibility for them to participate in local political power. During the following centuries, the beneficiaries of the entail were part of the city's political council, and their second cousins went to the University of Mexico to participate in the monarchical bureaucracy, both in Mexico and in other colonies or even in the very metropolis (Ramírez González 2013).

Several generations went by between the 15th and the 17th centuries until the descendants of that woman burned by the Inquisition at the end of the 15th century managed to do away with the civil, political and social restrictions imposed upon the descendants of Jews in the Iberian Peninsula. In the original deed of foundation of the entail, in 1624, one of Hernando Ortiz's nephews, Juan de Bojórquez, included a clause prohibiting the heirs of the bond from marrying women of Jewish descent because, the text says, "it has been seen from this generation and its descendants that erring in one's faith causes one to be sullied and produces great damage to the soul, as well as to the body and to one's estate" (Fernández de Recas 1965). This reads as a social and economic strategy on the part of Ortiz's nephews and nieces to negate the Jewish past of their ancestors and to distance themselves from their history in order to enjoy their rights as full-fledged members of their society. Almost at the same time, in 1625, another of Ortiz's nephews, Antonio de Hinojosa, completed the separation of the family from its Jewish past by obtaining a letter vouching for "cleanliness of blood" for his generation and the next ones, issued in Madrid by the Supreme Inquisition. The document acknowledges that Hernando Ortiz had lost his official functions due to his grandparents, but that thanks to his merits and to those of his nephews, they were considered by the Inquisition, from that moment on, as "old Christians", enjoying full civil and political rights.

The path followed by Hernando Ortiz de Hinojosa first as a student and then as a professor and member of the academic council at the University of Mexico acquires special meaning in this long-term history. The university and the education he received in it were Ortiz's best recommendation to the bureaucrats working for the Crown who arrived in the colony. Ortiz was promoted thanks to the university and was part of the covenant existing between the Crown and the first children of Spaniards who were born in America: they assumed functions which integrated them into the monarchical system while the king ruled from a distance and without needing a strong army. My goal in this article is to describe the nature of this education and that of the covenant between the American colonizers and their king.

\section{Migrants to a Land of Conquest}

Diego and Juana, Hernando Ortiz' parents, reached Mexico City from Sanlúcar de Barrameda in Andalucía in 1538. Sanlúcar was the entrance and departure harbor for transatlantic boats to and from the Iberian Peninsula, but in spite of its geopolitical importance, the town only had one thousand permanent residents, even though a population which fluctuated at the rhythm of the landings had settled in the area of the port (Guillamas 
1858). Conversely, Mexico City was a large multiracial city of some 100,000 inhabitants (75,000 natives, 8000 citizens from the Peninsula, some 15,000 people of African origin and 2000 mestizos) (Altman 1991). The city had been half-demolished and was undergoing reconstruction, since only 17 years had elapsed since it had been conquered.

The most obvious mark left by the conquest was the gradual death of the native peoples, in very large numbers. Violence, hunger, slavery, the destruction of the social fabric and overwork added to the lack of immunity to European diseases caused a population drop of nearly $90 \%$ among the people of the central zone of today's Mexico during the 16th century. Those are the most pessimistic figures (Borah 1989; Assadourian 1989).

Since 1535, Mexico City had been the capital of the Viceroyalty of New Spain, with Viceroy Antonio de Mendoza acting as its leader. The Audiencia (highest court) of Mexico was in charge of justice, but also of some government affairs; both relied upon the work of officials of lesser importance, such as the correctional judges who held power at the municipal level (Shäfer 2003; Ruiz Medrano 1991; Gibson 1984). Thanks to this incipient political organization, the king of Castile was trying to take control of a territory which was disputed not only by the indigenous populations but also by the conquistadores (conquerors); the latter had managed to take advantage of the indigenous labor force through an institution called Encomienda, which consisted in giving a group of workers for free to a conquistador in return for his work of conquest. The Crown gradually positioned itself between the conquistadores and the indigenous people to gain control over the colonial government.

In order to achieve its goals, during the 1530s, the Crown encouraged the emigration of entire families and prohibited the crossing to bachelors or men traveling without their wives. New Spain became the destination of choice for emigrant families (Boyd-Bowman 1963, 1967). This explains why Domingo de Santa María, a conquistador who had become a Dominican friar, decided to bring his sisters to New Spain; one of them was Juana and she came with her husband Diego. They were the parents of Hernando Ortiz.

By migrating with his wife's family, Diego was able to avoid the ban on passage to America as a descendant of Jews. Perhaps the Crown was lax with its restrictions, given the need to populate the conquered land. It is also possible that the Dukes of Medina Sidonia, who had the power to issue permits to go to America, decided to support the crossing of some of the conversos they had sheltered in the town of Sanlúcar (Ramírez González 2013). On the other hand, there were days when thousands of people embarked from that small port, which must have made control difficult. On 6 April, 1538, two expeditions left Sanlúcar. One was headed for the conquest of Florida and consisted of ten boats with about a thousand passengers on board; the other was composed of 20 ships bound for New Spain. We remain without information on the number of passengers they had on board (Guillamas 1858). Hernando Ortiz's parents belonged to that second group and were probably traveling after falsifying some personal documents (Ramírez González 2013).

The crossing between Sanlúcar and the port of Veracruz in New Spain usually took about two months (Martínez 1999). However, from that harbor to Mexico City, there was a mule driver's route that could take from one to three months (Hoberman 1993). The long journey undertaken by Diego and Juana allowed them to leave behind the social limitations imposed upon the descendants of Jews by the inhabitants of a town such as Sanlúcar, which were based on civil and political restrictions imposed by the Iberian monarchy on conversos; additionally, the trip came with the promise of a rich colonial territory.

Diego and Juana arrived in Mexico City that same year; by then, the conquistadores had already divided up among themselves the indigenous people who would labor for them in the encomienda system; furthermore, the Crown was reluctant to offer more encomiendas to the emigrants because it wanted to diversify the economic activities of the viceroyalty. However, with the discovery of the Taxco mines in 1534, silver began to be seen as the most important source of wealth in America. Soon, the exploitation of indigenous labor and the overall economy were oriented, directly or indirectly, toward mining (de Mendoza [1550] 
1873). America gained a solid reputation as a destination where Castilian emigrants could reinvent themselves.

In Mexico City, Ortiz's parents became farmers and neighbors. They had a total of ten children, five girls and five boys, but the two oldest died, one at age 20 and the other at age 12. Hernando Ortiz was the oldest of the living boys. He was born in early 1544 and baptized in Mexico City's cathedral. That same year, another 41 boys and 59 girls born in Mexico City to parents from the Peninsula were baptized (Ramírez González 2019). The members of those first generations of children of conquistadores and first settlers from the Peninsula were known as "native born" or criollos (Martínez 2019). An unprecedented destiny opened up before them: they were neither conquistadores nor immigrants like their parents, but they inherited their traditions and aspirations to be fulfilled in a society without many formal possibilities for their development.

In Mexico City, in 1544, there were no institutions in which to educate a man for life and hope to turn him into a scholar or a knight as there were in the peninsula. It was not possible in New Spain to forge a path like that of Hernán Cortés, who was a native of a small village in Extremadura, had been trained at the University of Salamanca and had become a conquistador and Marqués del Valle in New Spain.

\section{A University in a Land of Conquest}

From very early on, the conquistadores and settlers in New Spain petitioned the king for a university where their children could study. It had also been requested by the first archbishop of Mexico in order to clarify the problems of faith caused by evangelization. The viceroy himself had considered it unnecessary to educate the Mexican indigenous people who were already studying at the Tlatelolco school, but useful for offering outings to the children of Spaniards. Of all the supporters of the initiative, it was the colonizers who saw the process to its end and achieved the desired foundation of a university as part of the negotiations with the Crown on the political organization of the colonial territories. In 1551, the king issued three proclamations founding a university in Mexico City, with some of the privileges of the University of Salamanca and financed by the Crown (Pavón 2010).

The university began operating on 3 June, 1553, with lecturers for the main chairs of the faculties of arts, theology, canon law and civil law. Most of the professors were royal officials or friars for whom teaching was extra work. The students were the children of conquistadores and of the first peninsular colonizers, and the indigenous people were excluded from university studies during the 16th century. Some of the first students enrolled were clergymen or friars, for whom the university offered an education for their ministry. I have shown in another study how the first students who graduated did so painstakingly around 1557, and little by little they started occupying government positions and became university professors to achieve the consolidation of that nascent colonial university (Ramírez et al. 1989; Pavón Romero and González 1989). Hernando Ortiz was an active part of this first group of university students who helped consolidate the very institution in which they were studying.

\section{First University Student from an Emigrant Family of Conversos}

We have little information about the childhood of Hernando Ortiz de Hinojosa. We know that as a child he studied grammar in the Dominican convent of Amecameca, a town near Mexico City, perhaps on the recommendation of his maternal uncle who was a friar of that order (Ramírez González 2019). We also know that the family had sought a university education for their oldest son: Gomez first enrolled, before dying at the age of 20 while still a student. The brother who enrolled after him died even younger, at 12 . Hernando became the firstborn, and he was the only one of his siblings to pursue a university career.

Hernando's two younger brothers met with different fates: Diego married the daughter of judge of the High Court of Mexico and worked as a correctional judge in several towns near the city. Meanwhile, Hernando's younger brother Pedro became a parish priest and worked in various parishes also near the city (Ramírez González 2019). 
The three surviving male members of the Ortiz family were royal officials in the colonial administration, in both the civil and the ecclesiastical bureaucracies. The children of those converted Jewish immigrants who arrived in Mexico City as colonizers did not yet have the privileges reserved to the conquistadores. However, they could lend their services to the Crown and thus consolidate the fragile monarchical power that existed at the time. Thus, it seems that the king relied on those colonizers from the second wave to counteract the power of the conquistadores who owned encomiendas, also known as encomenderos.

Very soon, however, these colonizers started to develop kinship ties with other sectors of the growing society, including the encomenderos and the merchants who were gaining power. The five sisters of Dr. Ortiz played key roles in such alliances, thanks to the support of the successful academic career of their brother (Ramírez González 2013).

Hernando Ortiz entered the University of Mexico around 1561, at the age of 17, as a student of arts or philosophy, and remained there until his death in 1598, when he was 54 years old. I have researched his trajectory in detail and recently published a book about his life, the main lines of which I shall develop below (Ramírez González 2019).

Hernando Ortiz's first appearance in university records was not as a student but as a student representative, that is, a defender of students' rights before the university administration. When Ortiz was designated, he was 19 years old. From then on, Ortiz participated in the university's administration, serving either as a deputy (in charge of finances) or as a full professor.

Hernando Ortiz graduated from the University of Mexico with a Bachelor of Arts in September 1564 after studying philosophy for three years. During those first years as a student, he came into contact with professors and students allied with a political group organizing a rebellion in New Spain to establish a kingdom independent from that of Castile. Engineered by Martín Cortés, son of the famous conquistador, the rebellion was unveiled and dismantled before it could actually break out in 1566 (Tateiwa Igarashi 2016). After losing that possibility of forming part of an independent government, Hernando Ortiz focused his ambitions on the colonial institutions that would offer him a secure future within the triumphant monarchy: the university and the church.

In America, the church was part of the monarchical administration because the papacy granted the ecclesiastical administration of the conquered lands to the king of Castile, through a system called Patronato Indiano (Indian Patronage). The king nominated those in charge of ecclesiastical matters, such nominations being a way to consolidate his control over the colonies (Padden [1956] 2000; Schwaller 2000). Hernando Ortiz thus worked on the periphery of the monarchical structure. When he entered the university, he simultaneously began his career as a cleric: between 1561 and 1568, he obtained all the sacraments to become a priest and was named parish priest of San Mateo Huitzilopuchco, today Churubusco, a town that is now part of Mexico City and whose parish still exists.

In 1569, Hernando Ortiz earned a bachelor's degree in theology, and that same year, he obtained a chair in the School of Arts, thanks to the students' votes. He received a Master of Arts the following year. Thus, at the age of 25, Ortiz was a parish priest and professor at the university. He had blazed a trail, together with other students of his generation, for the children of Spaniards born in Mexico City. He continued teaching philosophy at the university for 18 years until 1587, the year when he obtained a professorship at the school of theology. He was a full professor at that school when he died in 1598. During the 1570s and 1580s, Ortiz was the recipient of all the degrees that could be obtained in the faculties of arts, theology and law. If the university was designed to promote Americans, then he was definitely one of the beneficiaries.

\section{A Position within the Hispanic Monarchy}

Ortiz's career in the university and in the American church corroborates the political project elaborated by the Hispanic monarchy to attract criollos on American soil. Archbishop Alonso de Montúfar was one of the first advocates of such a plan. A year after taking over the archbishopric of Mexico, in 1555, Montúfar wrote to the Council of the Indies: 
"[...] having proprietary benefits [the appointment of parish priests], the natives of this land will be given the opportunity to study at the university; because they speak different languages and were born in this land, they will not wish to go to Spain; in a short time, this land will have the required ministers and will adopt the required languages" (Paso y Troncoso 1939-1942, vol. VII, pp. 307-14). With these directives, Montúfar was entrusting the administration of a parish to the young Hernando Ortiz, in 1569 (Lundberg 2009).

The project of a criolla church was taken up again by Pedro Moya de Contreras, from 1573, when he succeeded Montúfar at the archbishopric of Mexico. This time, the archbishop had secured royal support through Juan de Ovando, a favorite of the king. Ovando had organized a Junta Magna in 1568 to solve the problems of American evangelization and was appointed president of the Council of the Indies from 1571 (Poole 2004). When Alonso de Montúfar was still archbishop of Mexico in 1569, Juan de Ovando had written surveys containing a series of questions in order to better assess the colonial reality; all the parishes of the empire were required to come up with information to fill out those surveys. The young Hernando Ortiz, who had recently been appointed parish priest of Huitzilopuchco, answered in a timely manner all the questions asked by the Crown, thus collaborating to defining the contours of an American identity. The information was used by Moya de Contreras, who decided to rely on that group of young academics, who were also members of the secular clergy, to achieve the systematic organization of an American ecclesiastical hierarchy. The archbishop suggested that the king appoint the most outstanding parish priests to hold intermediary positions in the ecclesiastical hierarchy, acting, for instance, as clerics of the cathedral. Moya de Contreras gradually gained the power to implement his project, and from 1571, he was Inquisitor of Mexico; moreover, between 1584 and 1585, he was viceroy of New Spain. Shortly before his death in 1592, Moya became president of the Council of the Indies. He was perhaps one of the few leaders of the Council of the Indies who had worked with the criollo clergy of the archbishopric of Mexico. He eventually gained direct access to the king, as well as control over American affairs through the Council of the Indies: he was familiar with both ends of the Spanish monarchical power pyramid (Poole 2004).

Hernando Ortiz was positioned on the lowest rung of the monarchical system of opportunities and power linking the American colonies and the metropolis. That structure was placed under the authority of Felipe II, was controlled by his protégé Juan de Ovando and included the Archbishop of Mexico Pedro Moya de Contreras, who bound the criollos together in this monarchical chain.

As parish priest of an indigenous town, Hernando Ortiz had contact with the native populations. He knew Nahuatl and preached to them in their own language, but at the same time, he provided the Crown with information about them. In addition, Ortiz also belonged to the colonizers who claimed benefits for themselves within the monarchical bureaucracy.

\section{A Career Meandering along Bureaucratic Promotions}

From 1575 on, Hernando Ortiz de Hinojosa became the topic of various dispatches in Mexico City and gained supporters so that his merits as an academic and parish priest would be recognized and rewarded with promotions up the ecclesiastic hierarchy. In 1575, he was warmly recommended to the king by the archbishop to be the recipient of a canonry in some American cabildo (municipality). The ecclesiastical municipalities constituted boards of the government and justice supporting the bishops and archbishops. They usually consisted of 12 clergy members, some of whom had particular honorary functions, such as the responsibility of teaching in the master school (Dussel 1970). Additionally, in the cathedrals, there were prebendaries and lower prebendaries, who performed low functions within the cathedral hierarchy.

Hoping to be listened to at court, Moya de Contreras appointed Hernando Ortiz as an assessor of books, a job he held until his death. The licenses he issued include at least nine books published in Mexico City during that era. In 1576, the king appointed Hernando 
Ortiz to occupy a lower prebendary position in the cathedral of Mexico. The office did not satisfy Ortiz, and thus he continued looking for support to become a canon of Mexico. The archbishop issued a new recommendation to the king, asking him to nominate "the children of this land", for in this manner, "all would be encouraged to devote themselves to education and virtue" (Paso y Troncoso 1939-1942, vol. 12, p. 21).

In 1585, Moya de Contreras invited Hernando Ortiz to participate as a consulting theologian in the third Mexican provincial council; there, Hernando debated with the main American ecclesiastic authorities about the future of the church and the society of New Spain. However, the monarch did not take his accomplishments into consideration nor other recommendations until 1589 when Ortiz was appointed a canon of Mexico's cathedral. The viceregal authorities acknowledged the importance of this appointment, since it would inspire young people from New Spain to pursue a career in the humanities, and thanked the king for the nomination.

Three years later, in 1592, Ortiz wanted to be a judge of the Inquisition. As I previously mentioned, the Inquisition prevented him from doing so, since his ancestors had been Jews in Sanlúcar de Barrameda.

The tradition of barring certain people from access to full civil and legal rights prevailed over the modernizing efforts of some monarchical officials who attempted to be more inclusive during the second half of the 16th century. However, even knowing the history of his ancestors, the king named Ortiz substitute bishop of Guatemala in 1596, two years before his death. The American church hierarchy could accept a converted Jew, but the Inquisition could not.

Hernando Ortiz' career was cut short by a past history that he was not responsible for. However, being involved in institutions was not the only strategy Dr. Hernando Ortiz resorted to. Besides dedicating himself to an academic career, he had become a respected figure in Mexico City and had established a kinship system, via the marriages of his sisters, with the most important sectors of colonial society.

\section{Social Prestige}

\subsection{Representative of the New Spain Clergy}

Besides his academic or clerical missions, Hernando Ortiz undertook other tasks for which he was recognized by his peers as a man of great worth for New Spain.

In 1583, Hernando Ortiz de Hinojosa became a spokesperson for the clergy of Mexico in their bid for winning ecclesiastical appointments in America. The clergymen joined the Brotherhood of San Pedro, which gathered 100 priests but claimed to represent more than 200, many of which were without any office or benefice (Ramírez González 2019). Ortiz defended the New Spain clergy from the bad reputation of avoiding royal justice and revived their prestige: he presented them as priests who knew the Nahuatl language, and who were hard-working and loyal to the monarchy. Despite its fragile beginnings, the brotherhood survived the entire colonial period.

\subsection{Protector of an Anchorite}

In 1584, Hernando Ortiz de Hinojosa left his parish in Huitzilopuchco to become the dean of the Santa Fe Hospital on the outskirts of the city. It was an institution founded by Vasco de Quiroga in 1532 and inspired by the Utopia of Thomas More (Warren [1963] 1997). Hernando Ortiz invited Gregorio López, an anchorite and wise man very much appreciated in New Spain, to live in the vicinity of the hospital, in a hermitage built especially for him. López arrived in Santa Fe in May 1589 and immediately drew the attention of visitors of all kinds (Losa [1613] 1727). The anchorite was considered a saint, but he was also reputed to be a Lutheran and had been accused of being Jewish. However, Ortiz backed him up, and his support earned him the favor of López's followers, including the viceroy of New Spain himself, Luís de Velasco. López's reputation as a saint lasted during the 17th and 18th centuries, when the papacy was petitioned for acknowledging his holiness, without any success (Rubial 1999). 


\subsection{His Library}

Hernando Ortiz put together a library of almost seven hundred titles which he described as "the most and the best that exist in these regions" (Ramírez González 2019, p. 237). From the inventory of books made after his death, we know that it was one of the most important academic libraries established in America at the end of the 16th century. It contained books in Spanish, Latin, Greek and Hebrew — as he put it—and also contained books in Nahuatl and Tuscan. There were books published in many different European cities, as well as in Mexico. Various cultural traditions from Europe and America come together in its midst. Books of theology, philosophy and the law prevailed, but there were also dictionaries and grammar books, along with chronicles, in addition to classical and modern literature.

After Ortiz's death, the library was sold to pay off his debts, incurred from the dowries for his sisters' marriages that he owed to his brothers-in-law. He also earmarked a sum to pay for his burial and to leave an inheritance for his nieces and nephews.

\section{Kinship Networks}

Hernando Ortiz de Hinojosa took advantage of his social prestige and his career in the university and the church to strengthen his family group. He paid for dowries so that his sisters would make marriages that amounted to prestigious alliances for the family.

His older sister, Violante de Hinojosa, was married to a businessman, Hernando Zarfate. He was in charge of providing some of the wine for the manufacturers of the ships that sailed to the Philippines from New Spain in 1564. However, his business was not always steady, and Zarfate was arrested for debt around 1565. This couple had three children; one of them was a Dominican friar and evangelizer in the Philippines, and another was a university doctor and canon of Mexico, like his uncle Hernando Ortiz (Ramírez González 2013).

Hernando Ortiz's second sister, Isabel de Hinojosa, was married to Jerónimo Cataño Bohórquez, a wealthy merchant who was based in Mexico City. He had a store in which books were sold, among other things, but he was also involved in real estate and mining. Jerónimo and Isabel had two sons, Juan and Diego, and a daughter, Ana. Ana joined the convent of Jesús María; Juan became a Dominican friar, and he eventually became bishop of Venezuela and of Oaxaca, where he established an entail for his nephew, Diego's son (Ramírez González 2013).

His third sister, named Agustina Riquel de Hinojosa, was married to Antonio Bravo, a second-generation encomendero. It seems that the encomienda did not yield much wealth to that family. They had two sons and two daughters. María joined the convent of Jesús María as a nun, while Juana remained single and received an inheritance from her uncle Hernando. Her sons, Antón and Diego, did not inherit their father's encomienda, and their track is quickly erased, although one of them, Diego, was a scholar just like his uncle (Ramírez González 2013).

The fourth sister of Dr. Ortiz was Inés Hinojosa, who married Alonso de Mansilla, a wealthy merchant from Seville; he was apparently of Arabic descent, as some sources considered him a "Moor". Alonso moved to New Spain around 1560, when hostilities against the Moors were growing and eventually resulted in the Rebellion of the Alpujarras between 1568 and 1570 . He seems to have been a wealthy merchant, but testimonies indicate that Mansilla went bankrupt. The couple lived in a house on Tacuba Street, which came with a store. They had three children. Francisco went to Peru, Juan became a captain and Antonio, who took the name of Hinojosa, was a university student and became a Dominican friar. He emigrated to Madrid, where he received his proof of "cleanliness of blood" by the Supreme Inquisition, of which he became a judge. He also wrote several books (Ramírez González 2013).

Hernando Ortiz's younger sister was Petronila de Hinojosa, who married merchant and landowner Antonio Troche. The couple took over the houses that had been their older sisters'. In addition, the two founded a cattle ranch in the Toluca Valley, which they then bequeathed to their son and daughter, Andrés and Juana (Ramírez González 2013). 
Overall, it seems that Hernando Ortiz's sisters who married merchants were economically and socially better off than the one who married an encomendero. In contrast, the younger sister and her husband made a venture into livestock farming, another business that was beginning to flourish at the beginning of the 17th century and was even more stable than commerce.

On the other hand, the male nephews followed similar careers to Hernando's but were more successful, although some chose marriage. For the nieces, the options seem to have been entering the convent, marriage or spinsterhood.

\section{Conclusions}

The life of Hernando Ortiz enables us to understand how the New Spain society functioned after the conquest. Considered as long-term history, it shows how emigration and academia allowed this family of conversos to become part of the criollo elite that was taking shape in Mexico City, the capital of the Viceroyalty of New Spain. In just three generations, the family was able to regain the full social, civil and political rights that were previously denied to them in the Iberian Peninsula because they were of Jewish descent. In return, they denied their ancestors. The University of Mexico, founded in the land of conquest, was a pivotal institution during the 16th century in guaranteeing the children of the conquerors and colonizers a prominent position among the monarchical structure of the Hispanic empire.

This particular trajectory invalidates the notion that Jews did not enroll in university in Mexico and were instead involved in commercial activities or lived in rural communities in New Spain. We know Ortiz's case because, in addition to being a university student, he endeavored to be a judge of the Inquisition. Had he not done so, we would never have known of his Jewish origins. This fact shows that it was possible for a descendant of Jews to integrate into the highest political and social levels of society in New Spain, as long as those origins remained hidden.

Funding: This research was funded by DGAPA, UNAM, PAPIIT IN402719.

Institutional Review Board Statement: Not applicable.

Informed Consent Statement: Not applicable.

Conflicts of Interest: The author declares no conflict of interest.

\section{References}

Altman, Ida. 1991. Spanish Society in Mexico City After the Conquest. Hispanic American Historical Review 7: 413-45. [CrossRef]

Assadourian, Carlos Sempat. 1989. La despoblación indígena en Nueva España y Perú y la formación de la economía colonial. Historia Mexicana 151: 419-49.

Borah, Woodrow. 1989. Europa renacentista y la población de América. In El pasado de México: Aspectos Sociodemográficos. Edited by Sherburne F. Cook and Woodrow Borah. Mexico City: Fondo de Cultura Económica, p. 416.

Boyd-Bowman, Peter. 1963. La emigración peninsular a América. 1520-1939. Historia Mexicana 13: 165-92.

Boyd-Bowman, Peter. 1967. La procedencia de los españoles de América. 1540-1559. Historia Mexicana 17: 37-71.

Caro Baroja, Julio. 2000. Los judíos en la España Moderna y Contemporánea. Madrid: Istmo, vol. 2.

Carrillo Cázares, Alberto. 2006-2011. Cuadro cronológico de las labores del Concilio tercero provincial mexicano. In Manuscritos del Concilio Tercero Provincial Mexicano (1585). Edited by Alberto Carrillo Cázares. Mexico City: Colegio de Michoacán y Universidad Pontificia de México, 5 tomos.

de Cadenas, Vicent. 1988. Carlos I de Castilla, señor de las Indias. Madrid: Hidalguía, p. 300.

de Mendoza, Antonio. 1873. Relación, apuntamiento y avisos que por mandado de S. M. dio D. Antonio de Mendoza virrey de la Nueva España a D. Luis de Velasco. In Colección de Documentos Inéditos Relativos al Descubrimiento, Conquista y Colonización de las Antiguas Posesiones Españolas en América y Oceania (CDIAO). Madrid: Impresores Varios, vol. 26. First published in 1550.

de Salazar, Cervantes. 2001. México en 1554: Tres Diálogos Latinos. Edited by Miguel León Portilla. Translated by de Joaquín García Icazbalceta. Mexico City: UNAM, p. 77. First published in 1554.

Dussel, Enrique. 1970. Les Évêques Hispano-Américains. Défenseurs et Évangélisateurs de l'Indien. 1504-1620. Weisbaden: Verlag, p. 286.

Fernández de Recas, Guillermo. 1965. Mayorazgos de la Nueva España. Mexico City: UNAM, p. 509.

Gibson, Charles. 1984. Los Aztecas bajo el Dominio Español, 1519-1810, 2th ed. Mexico City: Siglo XXI.

Ginzburg, Carlo. 1976. Il formaggio e i vermi. Il cosmo di un mugnaio del ‘500. Turín: Einaudi. 
Gojman Goldberg, Alicia. 1984. Los conversos en la Nueva España. Mexico City: Enep-Acatlan-UNAM.

Guillamas, Galiano. 1858. Fernando, Historia de Sanlúcar de Barrameda. Madrid: Imprenta del Colegio de Sordo-Mudos y Ciegos, p. 544. Hoberman, Louisa Schell. 1993. Mexico's Merchant Elite, 1590-1660: Silver, State and Society. Durham: Duke University Press, p. 354.

Israel, Jonathan I. 2002. Portuguese Cryto-Judaism in New Spain, 1569-1649. In Diasporas within a Diaspora: Jews, Crypto-Jews and the World Maritime Empires (1540-1740). Leiden: Brill, pp. 97-98.

Losa, Francisco de. 1727. Vida del siervo de dios Gregorio López escrita por ... , cura de almas, que fue de la iglesia mayor de México y su compañero en la soledad. A que se añaden los escritos del Apocalypsi y Tesoro de Medicina, del mismo siervo de Dios Gregorio López, que antes Andaban Separados de su vida y se Dedican al Supremo Real Consejo de las Indias, Quarta Impression. Madrid: Imprenta de Juan de Ariztia, p. 441. First published in 1613.

Lundberg, Magnus. 2009. Unificación y Conflicto: La Gestión Episcopal de Alonso de Montúfar, OP, Arzobispo de México, 1554-1572. Zamora: El Colegio de Michoacán, p. 301.

Martínez, José Luis. 1999. Pasajeros de Indias. Viajes Transatlánticos en el siglo XVI. Mexico City: Fondo de Cultura Económica, p. 323.

Martínez, Gerardo. 2019. Medicina y Sociedad: Saberes, Discursos y Prácticas. Siglos XVI al XX. Coordinated with Gerardo Martínez. Mexico City: IISUE, p. 290.

Nesvig, Martin. 2009. Ideology and Inquisition: The World of the Censors in Early Mexico. New Haven and Londres: Yale University Press, p. 366.

Padden, Robert. 2000. The Ordenanza del Patronazgo, 1574: An Interpretive Essay. In The Church in Colonial Latin America. Edited by John F. Schwaller. Wilmington: Scholarly Resources, pp. 5-72. First published in 1956.

Paso y Troncoso, Francisco del. 1939-1942. Epistolario de la Nueva España. Ciudad de México: José Porrúa e hijos editor, 14 tomos.

Pavón, Armando. 2010. El gremio docto. Organización Corporativa y Gobierno en la Universidad de México en el siglo XVI. Valencia: Universitat de València.

Pavón Romero, Armando, and Clara Inés Ramírez González. 1989. La carrera universitaria en el siglo XVI. El acceso de los estudiantes a las cátedras. In Los Estudiantes. Trabajos de Historia y Sociología. México: CESU-UNAM, pp. 14-55, Reeditado en 1999.

Poole, Stafford. 2004. Juan de Ovando. Governing the Spanish Empire in the Reign of Philip II. Oklahoma: University of Oklahoma Press, p. 293.

Poole, Stafford. 2011. Pedro Moya de Contreras. Catholic Reform and Royal Power in New Spain. 1571-1591, 2th ed. Oklahoma: Universidad de Oklahoma Press, p. 365.

Ramírez González, Clara Inés. 2013. Universidad y Familia: Hernando Ortiz de Hinojosa y la construcción de un linaje, siglos XVI... al XX. Mexico City: Bonilla Artigas/IISUE-UNAM, p. 262.

Ramírez González, Clara Inés. 2019. 'En tierra donde la codicia impera...' Vida de Hernando Ortiz de Hinojosa, (Ciudad de México, 1544-1598). Mexico City: IISUE-UNAM, p. 278.

Ramírez, González, Clara Inés, and Armando Pavón Romero. 1989. De estudiantes a catedráticos. Un aspecto de la carrera universitaria en la Real Universidad de México durante el siglo XVI. In Claustros y Estudiantes, prologado y compilado por Mariano Peset. Valencia: Universidad de Valencia, vol. II, pp. 279-89.

Rubial, Antonio. 1999. La santidad Controvertida: Hagiografía y Conciencia Criolla Alrededor de los Venerables no Canonizados de Nueva España. Mexico City: Fondo de Cultura Económica/UNAM, p. 323.

Ruiz Medrano, Etelia. 1991. Gobierno y sociedad en Nueva España, Segunda Audiencia y Antonio de Mendoza. Mexico City: Gobierno del Estado de México/El Colegio de Michoacán, p. 407.

Schwaller, John F. 1987. The Church and Clergy in Sixteenth-Century Mexico. Albuquerque: University of New Mexico Press, p. 289.

Schwaller, John F. 2000. The Church in Colonial Latin America. Wilmington: Scholarly Resources, p. 252.

Shäfer, Ernesto. 2003. El Consejo Real y Supremo de las Indias. Salamanca: Junta de Castilla y León/Marcial Pons, vol. 2.

Tateiwa Igarashi, Reiko. 2016. La rebelión del Marqués del Valle: Un examen del gobierno virreinal en Nueva España en 1566. Espacio Tiempo y Forma. Serie IV, Historia Moderna 29: 135-61. [CrossRef]

Taylor, William B. 1972. Haciendas coloniales en el valle de Oaxaca. Historia Mexicana 23: 284-327.

Warren, J. Benedict. 1997. Vasco de Quiroga y sus Pueblos Hospitales de Santa Fe. Morelia: Universidad Michoacana de San Nicolás Hidalgo, p. 235. First published in 1963. 